\title{
Food waste reduction in supply chains through innovations: a review
}

\section{Lusine Aramyan, Matthew Grainger, Katja Logatcheva, Simone Piras, Marco Setti, Gavin Stewart and Matteo Vittuari}

\begin{abstract}
Purpose - Agri-food supply chains are facing a number of challenges, which cause inefficiencies resulting in the waste of natural and economic resources, and in negative environmental and social impacts. Food waste (FW) is a result of such inefficiencies and supply chain actors search for economically viable innovations to prevent and reduce it. This study aims to analyse the drivers and the barriers that affect the decision of supply chain operators to adopt innovations (technological - TI, organisational- Ol and marketing - MI) to reduce FW.

Design/methodology/approach - The analysis was carried out using a four-step approach that included: a literature review to identify factors affecting the decision to adopt innovations; analysis of FW drivers and reduction possibilities along agri-food supply chains through innovations; mapping the results of Steps 1 and 2 and deriving conclusions regarding the factors affecting the adoption of innovations to reduce and prevent FW.

Findings - Results show that different types of innovations have a high potential in reducing and preventing FW along the supply chain; however, they still must be economically feasible to be adopted by decision makers in the food supply chain. $\mathrm{Tl}, \mathrm{OI}$ and $\mathrm{MI}$ are often interrelated and can trigger each other. When it comes to a combination of different types of innovation to reduce and prevent FW, a good example of combining $\mathrm{TI}, \mathrm{OI}$ and $\mathrm{MI}$ may be observed in the retail sector in Europe. Here, innovative smartphone apps (TI) to promote the sale of products nearing their expiration dates (OI in terms of organising the sales differently and $\mathrm{Ml}$ in terms of marketing it differently) were developed and adopted via different retailing channels, leading to the creation of a new business model.

Practical implications - This study analyses the drivers of FW generation together with the factors affecting the decision to adopt innovations to reduce it and provides solutions to supply chain operators to prevent and reduce FW through different types of innovations.

Originality/value - Literature has not systematically addressed innovations aiming at the reduction of FW yet. This paper provides a comprehensive literature review of the determinants of innovation adoption and offers a novel view on the problem of FW reduction by means of innovation, by linking factors affecting the decision to innovate with FW drivers.
\end{abstract}

Keywords Supply chain, Food waste, Technological innovation, Organisational innovation, Marketing innovation

Paper type General review

\section{Introduction}

Supply chain inefficiency contributes significantly to the 1.3 billion tons of food waste (FW) generated each year globally. In the EU-28, annual FW amounts to 180 kilograms per person, which constitutes 25\% of the food purchased by households (Canali et al., 2017; Gustavsson et al., 2011). In China, $\$ 32 \mathrm{bn}$ worth of food is thrown away every year, as food scraps comprise $70 \%$ of all waste nationwide, while 128 million Chinese live below the poverty line and often lack sufficient food (Zhou, 2013). In the US $40 \%$ of food goes uneaten, which is equivalent to $\$ 165 \mathrm{bn}$ each year (Gunders, 2012).

According to the recent literature on FW (del Río Gonzalez, 2005; Gustavsson et al., 2011; Aramyan and Valeeva, 2016; Canali et al., 2017), different types of innovations have a high
(Information about the authors can be found at the end of this article.)

Received 5 November 2019 Revised 7 May 2020 Accepted 25 May 2020

() Lusine Aramyan, Matthew Grainger,

Katja Logatcheva, Simone Piras, Marco Setti, Gavin Stewart and Matteo Vittuarig. Published by Emerald Publishing Limited. This article is published under the Creative Commons Attribution (CC BY 4.0) licence. Anyone may reproduce, distribute, translate and create derivative works of this article (for both commercial and non-commercial purposes), subject to full attribution to the original publication and authors. The full terms of this licence may be seen at http:// creativecommons.org/licences/ by/4.0/legalcode

This work was carried out under the auspices of the REFRESH project (http://eu-refresh.org/ about-refresh) and was funded by the Horizon 2020 Framework Programme of the European Union under Grant Agreement no. 641933. The authors are thankful to all colleagues of the institutions partners in the REFRESH Project for their contribution to the study. 
potential in reducing and preventing FW along the supply chain. The need for innovations to prevent and/or reduce FW has been highly emphasised (Canali et al., 2017). Hereby, one can think of investments in new technologies (e.g. new intelligent fridges and freezers that display the content and the expiry date of certain food items, improved storage environment, better packaging, advanced software tools for better production planning, precision farming tools such as drones that provide accurate information about harvested plants and minimise losses or crop framing sensors that provide accurate information on crop health, moisture levels and soil nutrition in real-time), new services (e.g. redistribution of surplus food), marketing and branding (e.g. promotion on "wonky" products to be included in the supermarkets' assortments) Gustavsson et al., 2011; Aramyan and Valeeva, 2016; Canali et al., 2017). Companies may be willing to address FW but, from a business perspective, wasting food might be rationale because:

- the costs of reducing FW might be higher than the financial benefits (Waarts et al, 2011);

- pay-back time to investments may be long;

- investments may not be possible due to constraints in resources (business priorities);

- there may not be a ready market for the extra produce to be sold (high costs to establish new market-outlets); and

- investments may lead other supply chain actors to benefit as well.

In some cases, the latter problem reduces the potential of the investor to recover the investment costs (free-riding problem). The more innovative a new technology is, the larger are the potential spill-over effects (Czarnitzki and Kraft, 2007). First movers invest in improving the technology, and others can learn from their successes and failures. On the other hand, early adopters can benefit from being amongst the first movers in a market (Sporleder et al, 2008).

Thus, the expected benefits from investments in technology that reduces FW should outweigh current costs. Consequently, exploring the factors that influence agri-food supply chain operators' choices in innovation adoption is essential. To this end, the objective of this paper is to analyse the factors influencing the decision of agri-food supply chain operators (e.g. farmers, manufacturers, retailers) whether or not to adopt innovations to reduce FW. The study also suggests different potential solutions to reduce FW in supply chains through different types of innovations.

\section{Methodology}

The analysis of this study was carried out using the four-step approach depicted in Figure 1 below:

1. A comprehensive literature review is carried out to identify different types of innovations (technological, organisational, marketing innovation) and the drivers affecting supply chain operators' decision to adopt these innovations;

2. FW drivers are analysed based on the categorisation proposed by Canali et al. (2017) in their comprehensive literature review on drivers of FW. FW reduction opportunities

\section{Figure 1 Steps of the study}

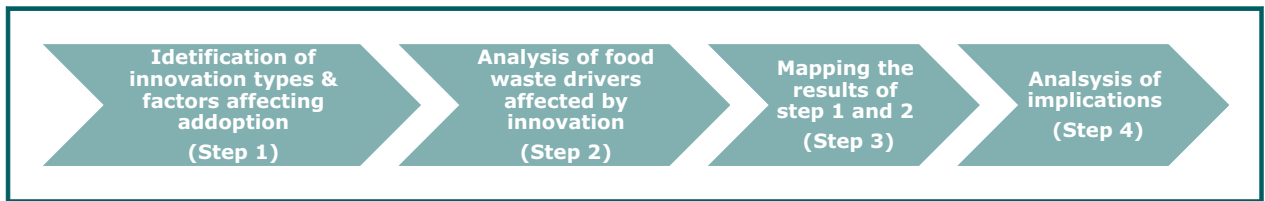

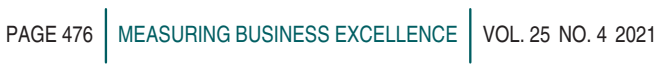


along the food supply chain through innovations are explored based on literature and on the work carried out within the FUSIONS project [1];

3. Mapping of the first two steps: FW drivers are linked to different types of innovations to identify which FW drivers can be addressed by what type of innovations and how (an illustrative examples of FW reduction opportunities by means of innovations); and

4. An analysis of the implications of the findings is provided.

In its turn a comprehensive literature review on innovation is carried out using the following steps:

- First of all the search terms have been defined (e.g. innovation adoption, technological innovation, organisational innovation, marketing innovation, etc.);

- Research has been carried out within relevant data sets (Scopus, Science Direct, etc.) and other electronic sources, based on the general terminology;

- Classification of the literature found has been carried out according to relevant keywords, that correspond to the types of the innovation because of the previous step; and

- Analysis of the state of the art has been carried out and the summary of the main evidence is presented in the current study.

\section{Literature review}

Innovation is recognised to play a central role in creating value and sustaining a competitive advantage (Baregheh et al., 2009). Innovations are to an increasing extent seen as the result of an interactive process of knowledge generation, diffusion and application (Todtling et al., 2009).

Rogers (2003) offered the following description of an innovation: "innovation is an idea, practice or project that is perceived as new by an individual or other unit of adoption" (Rogers, 2003, p. 12). The following types of innovation can be distinguished (OECD, 2005; Gunday et al., 2011):

- technological innovation (process and product innovation);

- organisational innovation; and

- marketing innovation.

The traditional concept of innovation in firms distinguishes product and process innovation and is often called technological innovation (Schmidt and Rammer, 2007). An organisational innovation refers to the creation or adoption of an idea or behaviour new to the organisation (Damanpour, 1996; Lam, 2006). It is the implementation of a new organisational method in the undertaking's business practices, workplace organisation or external relations (OECD, 2005). Marketing innovation is the implementation of a new marketing method involving significant changes in product design or packaging, product placement, product promotion or pricing (OECD, 2005). Thus marketing innovations represent ways in which companies can develop new ways of marketing themselves to potential or existing customers (Halpern, 2010).

\section{Technological innovation}

This section describes general factors from literature influencing the adoption of technological innovation [2].

Technological innovations (TI) can be related to products or processes. Product innovations involve the creation of new products or services through a process in which ideas are finally produced and commercialised by the firm, whereas, through process innovations, the firm develops or modifies new products or services. In general, process innovations are the 
implementation of a new or significantly improved production or delivery method. This includes significant changes in techniques, equipment and/or software. Product innovations refer to a good or service that is new or significantly improved. This includes significant improvements in technical specifications, components and materials, software in the product, user-friendliness or other functional characteristics (OECD, 2005). The evolution process from invention to innovation assumes that the innovator has the financial means, market knowledge and specific skills (Winter, 2006).

Several types of barriers are identified in the literature in the adoption of technological innovations. These barriers can be categorised into the following groups:

- Economic incentives, costs/finance and risks associated with the costs;

- Consumers' willingness to pay/acceptance of the innovation; and

- Territorial specificities.

Economic incentives, costs/finance and risks associated with the costs. A key barrier of adoption often discussed in the literature is the cost or financial factor. According to Long et al. (2016), the cost of many TIs is prohibitive, due to difficulties in initial commercialisation efforts. The expenses of establishing production facilities, as technology developers transform into technology producers, often imply that profits are hard to obtain and increase the costs of the innovative product or service (Cullen et al., 2013; Faber and Hoppe, 2013; Luthra et al., 2014). Furthermore, the availability of the necessary skills and capabilities to integrate and use the innovation has also impact on its costs for adopters. Specifically, the skills of the workforce and the firm's investment in such skills contribute substantially to product and process innovation in the food firms (Avermaete et al., 2004; Triguero et al., 2013). The capital life (long or short) of a current technological stock also affects the relative cost of innovations.

Other key factors affecting the adoption of innovation are uncertainty and risk perceptions (del Río Gonzalez, 2005; Johnson, 2010), market failures (such as information asymmetries) (Weber and Rohracher, 2012) and internal and external stakeholder pressures (Montalvo, 2008). Risk has often been considered a major factor in reducing the rate of adoption of new technology (Marra et al., 2003).

Fagerberg (2005) lists three key aspects of innovation processes such as:

1. uncertainty, due to the risk of failure;

2. speed of action, otherwise overrun by new innovations proposed by others; and

3. the structural strength of the social, legal and cultural context in which it is introduced.

When it comes to the adoption of technological innovation to reduce FW, the factors related to costs and risks might play a crucial role. The investment costs in technologies reducing FW might be higher than the financial benefits from it (Waarts et al., 2011). This coupled with the uncertainty and risk perceptions may become a barrier to the adoption of technological innovation. Rogers (2003) suggested that to reduce the uncertainty of adopting the innovation, individuals should be informed about its advantages and disadvantages to make them aware of all its consequences.

Consumers' willingness to pay/ acceptance of the innovation. Martinez and Briz (2000) argue that consumer acceptance is essential for the adoption of new technologies in food production, and the ultimate market success of any new product developed. An example of such consumer acceptance is represented by the study of consumer reactions to food irradiation. Despite the potential benefits to food manufacturers from irradiation (Blackholly and Thomas, 1989), consumers have clearly developed a negative attitude towards irradiated food products, thereby constraining the introduction of the technology (Henson, 1996). Therefore, "understanding whether and why consumers will accept innovations is 
critical for firms developing and marketing new products and services" (Claudy, Garcia and O'Driscoll, 2015). According to Mack (2018) for product innovations in the food industry, consumers might be risk-averse when it comes to new products such as for instance novel foods. There is a psychological barrier resulting from the notion that products they take directly into their body can potentially harm their health. Similarly, in the case of product and process innovation to reduce FW, it should be acceptable for consumers. For instance, with new technologies it is possible to prolong the shelf life of fresh products such as milk thus to reduce waste from its quick deterioration. However, consumers place great emphasis on the freshness of the products and prolongation of shelf life of milk can be associated with the product being less fresh (i.e. long-life milk instead of fresh milk) and less acceptable.

Territorial specificities. The environment in which innovation occurs influences development and outcomes. Territorial specificities, namely, those related to the technology, society, economy and institutions are important variables, which can enable or disable the innovation process (Abadi Ghadim and Pannell, 1999; Klerx et al., 2012; Avolio et al., 2014). These territorial specificities may affect the adoption of innovation both positively and negatively. Moreover, cultural barriers (linked to consumer habits and expectations) (Ceschin, 2013) and the credibility and authority of advisers or consultants (Guerin, 2001; Johnson, 2010) have also been identified as impacting adoption decisions. Depending on the enabling environment, innovation can be quickly adopted and spread in one place, while the adoption and diffusion may be restricted in other places. In other words, innovation is not likely to follow the same process of adoption and diffusion in different places, nor it will lead to the same outcomes (Avolio et al., 2014). When it comes to FW a good example of this dynamic is represented by the current trends of FW prevention and reduction initiatives throughout the EU, whose countries can be considered, respectively, innovators (e.g. UK, Sweden and Denmark), early adopters (e.g. Italy, France and The Netherlands) or laggards (e.g. Eastern European EU member states).

Table 1 summarises the findings from the literature on factors affecting the adoption of technological innovation.

\section{Organisational innovation}

This section describes general factors from literature influencing the adoption of organisational innovation.

Literature on organisational innovation (OI) focuses on the role of organisational structures, learning processes and adaptation to changes in technology and the environment. The latter includes the institutional framework and markets (OECD, 2005).

Ols can help increase a firm's performance by reducing administrative or transaction costs, improving workplace satisfaction, gaining access to non-tradable assets (such as noncodified external knowledge) or reducing costs of supplies (OECD, 2005). Furthermore, Ols

\section{Table 1 Summary table: findings from technological innovation}

Factors affecting the decision to adopt technological innovations

1. Economic incentives costs/finance and risks associated with the costs: e.g. investing in innovations to reduce FW may not be (very) cost-effective or pay-back time to investments may be long

2. Consumers' willingness to pay/ acceptance of the innovation

3. Territorial specificities, where the strength of the social, legal and cultural context plays a crucial role
Major references

Marra et al., 2003; del Río Gonzalez, 2005; Montalvo, 2008; Long et al., 2016; Cullen et al., 2013; Faber and Hoppe, 2013; Luthra et al., 2014

Henson, 1996; Blackholly and Thomas, 1989; Ceschin, 2013; Martinez and Briz, 2000

Abadi Ghandim and A. Pannell, 1999; Klerx et al., 2012; Avolio et al., 2014 
can improve the quality and efficiency of labour, enhance the exchange of information and improve firms' ability to learn and use new knowledge and technologies (OECD, 2005).

Factors related to OI can be categorised as follows:

- Economic incentives;

- Reorganisation of management and development of new business models; and

- Geographical scope.

Table 2 summarises the findings from the literature on factors affecting the adoption of organisational innovation.

Economic incentives. First of all, it is crucial to understand why firms innovate organisationally. According to OECD (2005) the ultimate reason for innovation, in general, is related to economic incentives and is directed to improve (OECD, 2005):

- Firm performance;

- Productivity; and

- International competitiveness.

Specifically, organisational innovations can be intended to increase a firm's performance by reducing administrative costs or transaction costs, improving workplace satisfaction (and thus labour productivity), gaining access to non-tradable assets (such as non-codified external knowledge) or reducing costs of supplies (OECD, 2005). Furthermore, organisational innovations can improve the quality and efficiency of work, enhance the exchange of information and improve firms' ability to learn and use new knowledge and technologies (OECD, 2005). When it comes to FW, organisational innovation can play a crucial role. Recently some new business models have emerged related to new manners of organizing the work to reduce FW on one side and making profits from other sides. For instance, new business models in the UK to produce jams and chutneys using surplus from wholesale markets (Stuart, 2009) or ReJuce, CO (UK): recycles food surpluses from local markets transforming it into juices, soups and smoothies.

Reorganisation of management and development of new business models. Kühne et al. (2007) argue that drivers of Ols in traditional food supply networks are the reorganisation of management, development of new business models, possibilities for collaboration (supplier, retailers and customers) and vertical integration. A type of $\mathrm{OI}$ is management innovation, which refers to the introduction of management practices new to the firm and intended to enhance company performance (Mol and Birkinshaw, 2009). Management innovation, in its turn, is a consequence of a firm's internal context (size, workforce, marketgeographical scope) and of the external search for new knowledge (from internal, market or professional sources). Namely, in addition to internal structural factors, management innovation comes about through the interaction with internal and external knowledge

\section{Table 2 Summary table: findings from organisational innovation}

Factors affecting the decision to adopt organisational innovations

Major references

1. Economic incentives mainly improved productivity and competitiveness

Schmidt and Rammer (2007) and OECD (2005)

2. Reorganisation of management and development of new business models (possibilities for collaboration-supplier, retailers, customers and vertical integration)

3. Geographical scope

Kühne et al. (2007), Mol and Birkinshaw (2009) and Polder et al. (2010)

Hofstede (1980) and Wu (2010)

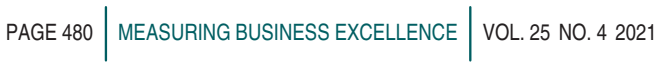


sources (Mol and Birkinshaw, 2009). Furthermore, in literature, a number of general and specific factors are identified which affect firms' OI. These general factors are:

1. ICT is particularly important for $\mathrm{OI}$ - the introduction of information technology is combined with a transformation of the firm, investment in intangible assets and a change in the relations with suppliers and customers (Polder et al., 2010); and

2. Other factors include:

- a firm's internal context (size, workforce, education level of the workforce and market-geographical scope); and

- the external search for new knowledge (Mol and Birkinshaw, 2009).

Specific factors affecting firms' innovation are: firms' characteristics, managers' characteristics, inter-organisational ties and intra-organisational ties (Hannan and Freeman, 1984; Mol and Birkinshaw, 2009).

There are two perspectives on the role of OI:

1. it occurs during process or product innovation; and

2. it could be a necessary precondition for technical innovation.

In relation to FW reduction, organisational innovation specifically related to ICT in combination with new business model developments can be promising. Currently, organisations and individuals around the world have developed and promoted numerous apps to alleviate the problem of FW. These apps help connect farmers to consumers, retailers to charities and growers to intermediaries in reducing food surplus. The examples of such apps are:

- "Food for all" which eliminates last-minute restaurant FW in Boston and New York City [3]. It connects customers to restaurants one hour before they close, for meal discounts as high as 80 percent;

- "Nofoodwasted" in the Netherlands which stimulates demand for discounted products with a best before date [4]. It alerts supermarket shoppers which items are approaching their expiration date, while users (consumers) can explore the available deals online; and

- In New York City, "goMkt" connects restaurants that have unsold food with customers looking for discounts [5]. By purchasing food as take-out through the app, customers save up to $75 \%$ off the original price - and reduce potential FW.

Geographical scope. The geographical scope is another moderator of the relationship between management innovation and firm performance. A wider geographical scope means that a firm may have to deal with cross-cultural administrations in different markets (Hofstede, 1980). Cultural differences increase the difficulty of implementing new management practices, especially if the cultural distance is large, as between of Asia and Western countries. Thus, the geographical scope may have different impacts on the adoption of innovation.

\section{Marketing innovation}

This section describes general factors from literature influencing the adoption of marketing innovation.

The concept of marketing innovation (MI) has been understood differently by different research disciplines (Carneiro, 2000). According to some authors, "Ml" can be defined as innovation in marketing programmes or methods, including the four Ps of marketing (Shergill and Nargundkar, 2005; Moreira et al., 2012) [6]. Economists consider Ml from the 
product and process perspective, while marketing researchers conceptualise it from a commercialisation viewpoint (Sood and Tellis, 2009; Gupta et al., 2016).

Moreira et al. (2012, p. 19) argue that the "ability to generate a variety of new products and services successfully and find new forms of communicating and distributing them is vital for many organisations, as the sustainability of marketing activities is an essential factor for adapting to the market and the immediate changes, new technologies and competitors' moves".

Factors affecting the adoption of MI can be divided into two main groups (See also Table 3):

1. Economic incentives mainly related to competitive advantage; and

2. Improving and/or innovating marketing initiatives.

Economic incentives. Shergill and Nargundkar (2005) suggest that MI is related to business performance. Moreira et al. (2012) state that $\mathrm{Ml}$ is the result of a whole set of alterations introduced by the company, influenced by a vast set of internal and external factors. Firms commit to an innovative marketing idea only after they have identified the contribution it makes to their competitiveness as an incentive to become innovative in their marketing practices (Sood and Tellis, 2009).

Literature suggests that $\mathrm{Ml}$ is mainly a consequence of competitiveness (Gupta et al., 2016). This type of innovation has often been discussed in the literature in relation to competitive advantage theory, concluding that innovativeness in the approach used to market a product is vital for the competitiveness of both buying and selling firms (Hunt and Morgan, 1995, 1996; Ren, Xie and Krabbendam, 2010). In this context, Naidoo (2010) finds that competitors' orientation and inter-functional coordination can lead to $\mathrm{Ml}$ and $\mathrm{Ml}$ could develop and sustain a competitive advantage based on differentiation and cost leadership strategies.

Improving and/or innovating marketing initiatives. Businesses are using $\mathrm{Ml}$ in improving and/ or innovating their marketing initiatives. Examples of such improvements are developing new services or reformulating existing ones, creating new distribution channels and discovering new approaches to management. These kinds of innovations represent new ways in which companies market themselves to potential or existing customers (Slater and Narver, 1994). MI can also be related to market research, price-setting strategy, market segmentation, advertising promotions, retailing channels and marketing information systems (Lin, Chen and Chiu, 2010). The adoption of internal R\&D, company size (i.e. turnover) and export-orientation can also lead to MI (Medrano-Sáez and Olarte-Pascual (2012). Furthermore, manufacturing companies were found to mostly innovate in product design and packaging, while service companies were found to be more engaged in $\mathrm{Ml}$ regarding product or service placement, promotion and pricing (Medrano-Sáez and Olarte-Pascual, 2012).

In relation to $\mathrm{FW}$ reduction, $\mathrm{Ml}$ can play an important role when it comes to innovations related to e.g. product and package design (smaller pack sizes to avoid FW, packages that are easy to empty, redesigned and improved food packaging to increase shelf life and provide more information regarding e.g. storage of the products, better explanation of "use by date" and "best before date" on labels), promotion and pricing (cutting back multi-buy

\section{Table 3 Summary table: findings from MI}

Factors affecting the decision to adopt of MIS

Major references

1. Economic incentives (mainly competitive advantage)

Gupta et al. (2016), Lin et al. (2010), Hunt and Morgan (1995, 1996), Ren et al. (2010) and Naidoo (2010)

2. Improving and/or innovating marketing initiatives with sub-factors such as adoption level of internal R\&D, company size

Moreira et al. (2012), Medrano-Sáez and Olarte-Pascual (2012) and Silva et al. (2012) 
promotions such as buy one get one free, replacing it with e.g. "buy one, get one later" (Sainsbury's and Tesco, UK)), retailing channels (e.g. promotion and selling of close to expiry date food via alternative/online channels).

\section{Interaction between the three types of innovation}

Innovation activities are thought to "influence each other and need to be implemented in conjunction" (Walker, 2004). Examples of such interrelationships were found between organisational, marketing and service (or product) innovations in public organisations, while process innovation and product innovations were found to be significantly correlated to each other in Chinese firms (Walker, 2008). A positive relationship was also shown between OI and process innovation, $\mathrm{Ol}$ and $\mathrm{MI}$, process innovation and product innovation and $\mathrm{Ml}$ and product innovation amongst Turkey manufacturing firms (Gunday et al., 2011). Schmidt and Rammer (2007) observe a close link between organisational and process innovation, as introducing new technologies in production or distribution may demand reorganizing business routines, which may trigger the introduction of new business practices or new organisational models. Organisational innovation may also occur in the course of product innovations. For instance, new products often induce the establishment of new products or sales divisions and call for reorganisation of workflows, knowledge management or external relations. Hence, technological (process and product) and non-technological (organisational) innovations should not be conceived as alternative activities; these are rather complementary strategies, which are more effective when combined (Schmidt and Rammer, 2007). However, Lam (2006) emphasises that the role of organisational innovation from another perspective: "economists assume that organisational change is a response to technical change, when in fact organisational innovation could be a necessary precondition for technical innovation". In this sense, organisational innovations are not only a supporting factor for product and process innovations; they can also have an important impact on firm performance on their own.

In relation to $\mathrm{MI}$, Schubert (2010) concludes that MI makes both product and process innovation more successful in German companies. Product and process innovations do not have a positive effect without $\mathrm{MI}$, and the combination of both technological and non-TI determines productivity gains (Polder et al., 2010). Creating a new product, a new service or a new business process cannot be considered an innovation unless being subjected to the marketing process. With this perspective, an effective innovation strategy is crucial for organisations in the process of marketing and producing innovation (Uzkurt et al., 2013).

\section{Food waste drivers in agri-food supply chains}

To understand how innovations can reduce FW, there is a need to explore how FW occurs. FW occurs in all stages of the food supply chain; however, the causes of FW are different amongst developed and developing countries (Gustavsson et al., 2011). In developing countries, the most significant losses take place at the beginning of the supply chain (at harvest and post-harvest stages) and are due to limits in the cultivation and harvesting, the lack of food-chain infrastructure, transportation and investment in technologies (Godfray et al., 2010), while in developed countries, FW takes place at the end of the supply chain (mainly at consumption stage), where surplus food generation, along with consumer behaviour, are the main causes (Buzby and Hyman, 2012; Gustavsson et al., 2011).

In the last decade, the causes of FW have been comprehensively discussed in literature by many authors. Thus this study is not devoted to another literature review on FW drives but uses already existing extensive literature. The drivers of FW have been extensively studied by Canali et al. (2017), who identify a total of 286 causes of FW generation, based on 171 literature references and on the direct experience of experts. Canali et al. (2017) categorises FW drivers into five main contexts. The table below provides an overview of the categories of FW drivers and explanatory examples. 
From Table 4 it can be concluded that the three main FW categories that can be addressed by innovations to reduce FW are categories: $a, c$ and $e$. The categories $b$ and $d$ are rather difficult (if not impossible) to influence by before-mentioned innovations, as $b$ entails population trends and dynamics, that are non-readily changeable, while $d$ relates to policy priorities which in general can have an influence on FW reduction, but can rather be addressed other means than via above-mentioned innovations.

\section{Examples of innovative solutions to reduce food waste}

While the previous section presents FW drivers, this section illustrates different examples of innovative solutions for FW reduction and links them to three types of innovation they belong to. The illustrative examples are mostly based on the work carried out within the EU FUSIONS project. Table 5 summarises these examples.

Analysing Table 5 it becomes obvious that $\mathrm{TI}$, OI and Mls offer promising possibilities in reducing and preventing FW. For instance in TI modifying fishing gears so that fewer nontarget species are caught or can escape will reduce fish waste by a significant amount [7]. Another example is the introduction of new technology for improving storage such as smart climate control systems to preserve perishable products, better refrigeration equipment, as well as control management such as the new intelligent fridges and freezers that could display the content and the expiry date of certain food items. Other examples of TIs are the introduction of better measurement systems to quantify the FW along the chain, by using of new intelligent scales and statistics systems. Electronic ordering systems and automatic ordering for predicting food demand more accurately will assist in avoiding overproduction and surplus. The examples of Ols are related to new manners of organizing the work to reduce FW. When it comes to FW related production errors, improper stock rotations, grading and sorting of products, it is possible to improve these processes by adopting business practices such as:

\section{Table 4 FW drivers}

FW drivers

a. Inherent characteristics of food and ways of its production and consumption

b. Social and economic factors and dynamics in population habits and lifestyles that are non-readily changeable

c. Individual non-readily changeable behaviors of consumers

d. Other priorities targeted by private and public stakeholders

e. Diversified factors

Source: Canali et al. (2017)

\section{Examples}

Perishability of food, difficulties with the predictability of supply and demand leading to overproduction, the limited possibility for consumers to accumulate individual stocks of food, etc.

Single-person households, young couples with small children, growing urban population, increased consumption of meals out of home, low price of food products, increasing wealth

Expectations of consumers towards food such as high quality, freshness, the possibility of acceding to broad quantities and varieties of food independently from the place, season and time, etc.

FW reduction and prevention may be a minor concern with respect to other priorities of private and public stakeholders. For companies FW is a good business (e.g. it generates profits due to sale volumes), so no incentives to reduce it. For public authorities, legislative provisions to improve aspects like food safety, food security, consumer information and animal welfare may overcome the concern for potential FW generation derived from such legislation

Mismanagement, inefficient legislation, lack of awareness or information and sub-optimal use of available technologies 
Table 5 Examples* of innovative solutions to reduce FW

Technological Organisational

1. Selective fishing gear to reduce bycatch

2. New technology for improving storage such as smart climate control systems

3. Access to modern equipment and techniques

4. Better measurement systems to quantify the FW along the chain; use of new intelligent scales and statistics

5. Electronic ordering systems and automatic ordering for predicting food demand more accurately, thus avoiding overproduction and surplus
Reduction of production errors, improper stock rotations, grading and sorting of products by adopting business practices such as:

a. Employee development and improvement of worker retention

b. Codifying knowledge

c. Better quality control and logistics mechanisms

Solving (cold) chain inefficiencies through workplace organisation: Improving inefficient relationships between suppliers and re-distributors by adopting new external relation schemes

Development of new business models in combination with ICT to promote numerous apps (e.g. "food for all", nofoodwasted), which require re-organisation of the work to alleviate the problem of FW
Marketing

Marketing practices regulated through increased cooperation between food supply chain operators

"Buy one now, get one later-later" (BUGOL) promotions The use of out-graded ("substandard") fruits and vegetables

New package design to adjust size and portion and increase the shelf life of the products

Reducing or eliminating differences in price per kilogram for packaging items

To reduce plate waste - better food quality, right portion size and menu choice

Note: *This table does not provide a comprehensive list of all possible innovations, it provides some illustrative examples

- employee development and improvement of worker retention;

- codifying knowledge: e.g. establishing databases of best practices, lessons and other knowledge; and

- better quality control and logistic mechanisms.

Another possibility is solving (cold) chain inefficiencies through workplace organisation: e.g. build-to-order production systems (integrating sales and production) or integration of engineering and development with production. Ol includes also improving inefficient relationships between suppliers and re-distributors by adopting new external relation schemes: e.g. new types of collaborations, new methods of integration with suppliers, procuring, distribution and additional services. When it comes to Mls, the role of the producers and retailers is crucial. Hereby marketing practices regulated through increased cooperation between food supply chain operators are important. Some examples of practices avoidable by means of cooperation are the fixation of best-before dating according to consumer expectations and not to the actual quality of products (WRAP, 2011). Hereby it refers to the perception of consumers that the shorter the best-before date, the fresher is the product, so the best-before dates set are shorter than in reality product's shelf life is. Selling of products in too large packages (Salhofer et al., 2008; Stenmarck et al., 2011) and the so-called "cannibalisation" effects of certain sales campaigns, which destabilise the demand structure and reduce the predictability of market forecast with impact on FW (WRAP, 2011; WRAP, 2012) are other avoidable practices. Examples of Mls related to promotions directed to FW prevention and reduction are, for instance, for instance promotion such as "buy one now, get one later" (BUGOL) (Canali et al., 2014), introduced by Tesco supermarkets.

The promotion and use of out-graded ("sub-standard") fruits and vegetables, while providing knowledge to consumers about the nutritional value of products of imperfect size/shape to 
reduce discards (Barila, 2012) and promoting of sub-standards products such as the practice introduced by ASDA supermarkets "wonky veg box", containing imperfect in-season vegetables with $30 \%$ discount (The Guardian, 2016). Similar initiatives related to out-graded produce have been developed by the French retailer Intermarché that uses the term inglorious to name the ugly produce, in the UK by food retailer Harris Farms who launched its "imperfect picks" and by Rewe Group in Germany which offers "nonconformist produce" and Edeka (Germany) that launched the "nobody is perfect" produce (Calvo-Porral, 2017). New package design to adjust size and portion and increase shelf life of the products can also contribute to FW reduction. For instance, Morrisons' (UK) "great taste less waste" is a new packaging system with best-kept stickers, where consumers are advised on where food is best to be stored at home. Other solutions include reducing or eliminating differences in price per kilogram for packaging items which can lead to over-buying; exposing the goods with the shortest shelf-life; reducing prices to sell-before/best before date products (Stenmarck et al., 2011).

When it comes to a combination of different types of innovation to reduce and prevent FW, a good example of combining $\mathrm{TI}, \mathrm{Ol}$ and $\mathrm{MI}$ may be observed in the retail sector in Europe. Here, innovative smartphone apps (TI) to promote the sale of products nearing their expiration dates (OI in terms of organising the sales differently, and $\mathrm{Ml}$ in terms of marketing it differently) were developed and adopted via different retailing channels, leading to the creation of a new business model (e.g. "nofoodwasted" and "goMkt"). Another example of a combination of MI and TI adopted by British supermarket chains Waitrose and ASDA are automated temperaturecontrolled lockers for storing online grocery orders to be collected at a later time, targeted at consumers who prefer to shop online but cannot stick to certain delivery time.

\section{Mapping of the findings from the literature}

In this section, the results of the findings from the literature on drivers of $\mathrm{TI}, \mathrm{OI}$ and Mls are mapped against the drivers of FW and combined with possible innovative solutions to reduce FW. Figure 2 provides an illustrative mapping of the results.

When linking the different types of innovations to the FW drivers presented in Table 4, it becomes obvious that Tls to reduce FW can better target the first group of FW drivers "inherent characteristics of food and ways of its production and consumption" (group a in Table 4) e.g. by introducing new equipment or advanced ordering systems. To this end, it can be concluded that the target groups for $\mathrm{Tl}$ are predominantly producers/farmers, manufacturers and to some extent retailers.

Ol can be directed to the last group of FW drivers "diversified factors" (group e in Table 4) e.g. better management practices, new business models. This means that Ols to reduce FW are applicable to the operators in all stages of the agri-food supply chain.

Mls can be directed to the third group of FW drivers "individual non-readily changeable behaviours of consumers" (group $c$ in Table 4) e.g. adjusted market practices. This means that the Mls to reduce FW can be predominantly directed to the operators at end of the supply chain, mainly to retailers and to some extent manufacturers (e.g. when it comes to new package design, provision of information).

As discussed earlier in section "FW drivers in agri-food supply chains", the innovations studied in this research seem not to have a direct impact on FW drivers of the second and the fourth group, as these two groups represent either socio-economic developments or public/private priorities which are not easy to affect by any of the three innovations discussed here.

\section{Decision-making to adopt innovation}

Although innovations could play a crucial role in preventing and reducing FW, they still must be economically feasible to be adopted by decision makers in the food supply chain. The 


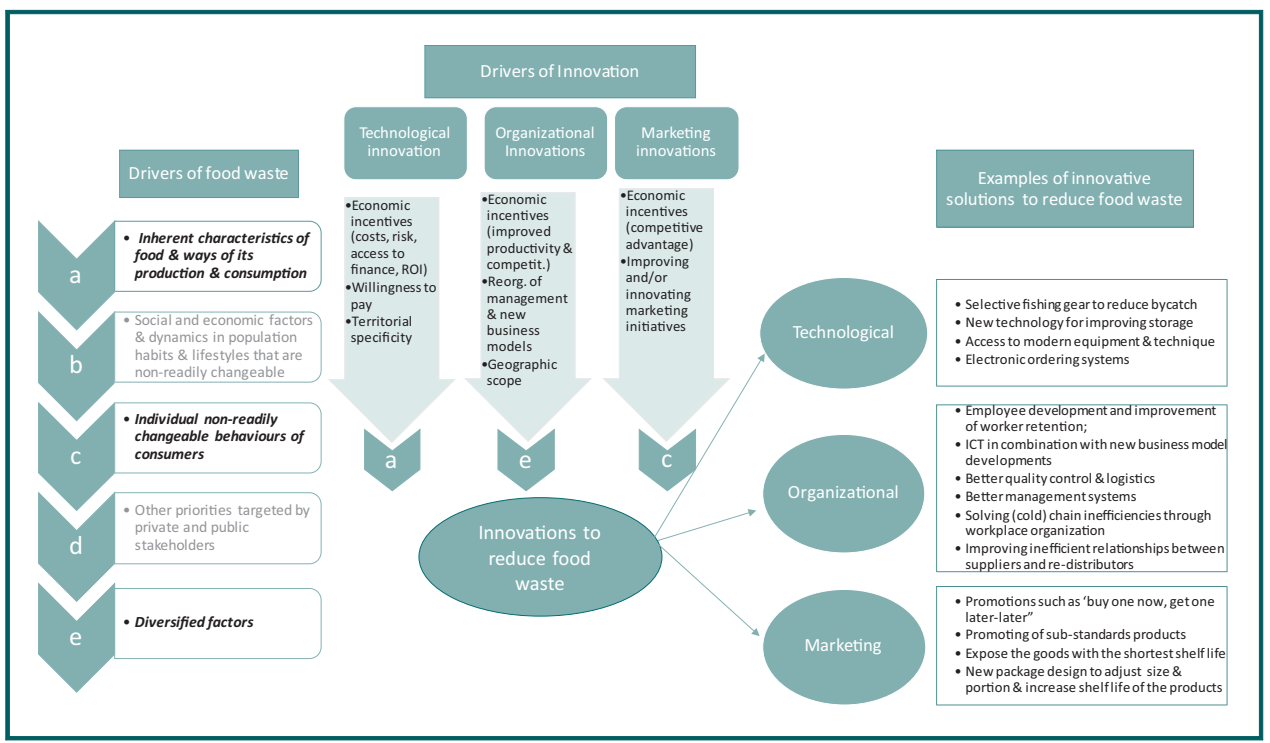

literature review showed that the ultimate reason for any type of innovation is generally related to the following factors:

- improve firm performance;

- improve productivity; and

- improve (international) competitiveness.

In literature, cost factors and the risks associated with these costs, are considered to be the most important determinants of both $\mathrm{Tl}$, as well as Ols. Besides, literate showed that product and process innovations are often interrelated with $\mathrm{Ol}$ and/or $\mathrm{Ml}$ and the combination of these innovations leads to better results (Lam, 2006; Schmidt and Rammer, 2007; Walker, 2008; Gundey et al., 2011). From the examples of innovative solutions to reduce FW it emerged that while TI is more applicable to upstream supply chain operators (e.g. producers/farmers, manufacturers and to some extent retailers), OI is applicable to the operators in all stages of agri-food supply chain and $\mathrm{MI}$ is more applicable for downstream operators (e.g. food processing and retail).

Literature showed that the geographical scope or territorial specificity is another important determinant of both $\mathrm{TI}$ and Ols. The cultural difference increases the difficulty of implementing new management practices, especially if the cultural distance is large. Depending on the enabling environment, TI can be quickly adopted and spread in one place, while adoption and diffusion may be restricted in other places. In general, innovation is not likely to follow the same process of diffusion in different places and is not likely to lead to the same outcomes (Abadi Ghadim and Pannell, 1999; Klerx et al., 2012; Avolio et al., 2014).

\section{Concluding remarks}

The study of decision-making in individual businesses remains a relevant issue when society is confronted with the negative externalities of food production and distribution, with FW being one of the most relevant examples of inefficient use of resources in the food supply chain. Technological change can help supply chain operators in reducing inefficiencies, but it only makes sense when there is no loss in their ability to satisfy the customer and when adaptive organisation practices are used. Extensive work is available on the assessment of drivers of FW. At the same time, although 
innovation has been devoted broad attention in the literature, no studies have linked the factors that determine the process of innovation adoption to the drivers of FW to achieve its reduction.

The objective of this paper was to analyse the factors affecting the decision of agri-food supply chain operators to adopt innovations to reduce FW and to indicate possible solutions to reduce FW through innovations. The paper's contribution to the knowledge of these themes may on one hand be beneficial for businesses, and on the other hand, can contribute to the societal need of finding solutions for the negative spill-overs of the current food system.

The literature review shows that the main reasons to adopt FW reducing innovations are strongly related to the firm's economic and financial position. Innovations are aimed at improving performance, productivity and/or competitiveness. Cost factors and the risks associated with these costs are crucial aspects of $\mathrm{TI}$, as well as non-TI.

The main conclusion following from the analysis is that FW drivers should be addressed in such a way that supply chain operators benefit financially and economically from the outcome. However, the expected gains from innovation are often difficult to assess. In general, literature shows that the three types of innovation are often interrelated and can trigger each other, as the introduction of new technologies in production or distribution may demand reorganizing business routines and development of new business models which in turn may require new marketing solutions.

In general, innovation is not likely to follow the same path of adoption and diffusion in different places, leading to different local outcomes. This is why some organisation systems are working easily in one country but have major difficulties to be implemented in others. A good example of this dynamic is represented by the current trends of FW prevention and reduction throughout the EU, whose countries can be considered, respectively, innovators (e.g. UK, Sweden and Denmark), early adopters (e.g. Italy, France and The Netherlands) or laggards (e.g. Eastern European EU Member States). Also at the individual business level, the adoption of innovation to prevent and reduce FW is an on-going process and, like in other sectors, businesses will divide into early adopters of new technologies or Ols and those lagging behind.

So, what can supply chain operators do to reduce FW? In an inventory of food reduction possibilities, good existing examples of innovative solutions were collected from the EU FUSIONS projects and beyond. Companies can raise awareness or train employees on the handling of the fresh perishable product (e.g. fruits and vegetables), improve planning, improve the quality and timing of inputs, implement or adapt packaging, storage and transport technologies, change marketing standards and reduce errors in production, influence consumer behaviour by, e.g. scrapping promotions such as "pay one get two" and re-distribute the surplus/overproduction through other marketing channels (e.g. donations, selling at a lower price, selling via apps/Internet).

In the light of the findings of this study, it might be interesting to focus future research on the assessment of the relationship between innovations reducing FW and a firm's performance. Furthermore, the relationship between reduction of FW by means of MI and a firm's image (as a performance indicator) could be explored.

\section{Notes}

1. For more information please refer to www. fusions-eu.org

2. The extension of this literature review on technological and organisational innovation can be found in the study of Aramyan and Valeeva (2016).

3. Four Ps as the marketing mix of product, price, promotion and place were introduced in marketing education by E. Jerome McCarthy in 1960.

4. https://foodforall.com/

5. www.nofoodwasted.com/

6. www.gomkt.com/

7. The incidental capture of non-target species during fishing such as dolphins, marine turtles and seabirds, which turn into fish waste). 


\section{References}

Abadi Ghadim, A.K. and Pannell, D.J. (1999), "A conceptual framework of adoption of an agricultural innovation", Agricultural Economics, Vol. 21 No. 2, pp. 145-154.

Aramyan, L. and Valeeva, N. (2016), "Socio-economic implications of food waste: economics of innovation, Project report”, EU Horizon 2020 REFRESH, Wageningen University and Research, Wageningen, pp. 3-58.

Avermaete, T., Viaene, J., Morgan, E.J., Pitts, E., Crawford, N. and Mahon, D. (2004), "Determinants of product and process innovation in small food manufacturing firm", Trends in Food Science \& Technology, Vol. 15, pp. 474-483.

Avolio, E., Blasi, C. and Cicatiello Franco, S. (2014), "The drivers of innovation diffusion in agriculture: evidence from Italian census data", Journal on Chain and Network Science, Vol. 14 No. 3, pp. 231-245.

Baregheh, A., Rowley, J. and Sambrook, S. (2009), "Towards a multidisciplinary definition of innovation", Management Decision, Vol. 47 No. 8, pp. 1323-1339.

Barila (2012), Oslo Manual: Guidelines for Collecting and Interpreting Innovation Data, available at: http:// essay.utwente.nl/75033/1/Mack_MA_BMS.pdf

Blackholly, H. and Thomas, P. (1989), Food Irradiation, Horton Publishing, Bradford, p. 81.

Buzby, J. and Hyman, J. (2012), "Total and per capita value of food loss in the United States", Food Policy, Vol. 37 No. 5, pp. 561-570.

Calvo-Porral, C., Medín, A. and Losada-López, C. (2017), "Can marketing help in tackling food waste?: Proposals in developed countries", Journal of Food Products Marketing, Vol. 23 No. 1, p[p. 42-60.

Canali, M., Östergren, K., Amani, P., Aramyan, L., Sijtsema, S., Korhonen, O., Silvennoinen, K., Moates, G., Moates, G. and Vittuari, M. (2017), "Food waste drivers in Europe, from identification to possible interventions", Sustainability, Vol. 9 No. 37, pp. 1-33.

Canali, M., Amani, P., Aramyan, L., Gheoldus, M., Moates, G., Östergren, K., Silvennoinen, K., Waldron, K. and O'Connor, C. (2014), "Drivers of current food waste generation, threats of future increase and opportunities for reduction", EU Fusions project, available at: www.eu-fusions.org/index.php/publications/ 265-establishing-a-common-framework-for-food-waste-definition-and-identifying-its-drivers.

Carneiro, A. (2000), "How does knowledge management influence innovation andcompetitiveness?", Journal of Knowledge Management, Vol. 4 No. 2, pp. 87-98.

Ceschin, F. (2013), "Critical factors for implementing and diffusing sustainable product-service systems: insights from innovation studies and companies' experiences", Journal of Cleaner Production, Vol. 45, pp. 74-88.

Claudy, M.C., Garcia, R. and O'Driscoll, A. (2015), "Consumer resistance to innovation - a behavioral reasoning perspective", Journal of the Academy of Marketing Science, Vol. 43 No. 4, pp. 528-544.

Cullen, R., Forbes, S.L. and Grout, R. (2013), "Non-adoption of environmental innovations in wine growing", New Zealand Journal of Crop and Horticultural Science, Vol. 41 No. 1, pp. 41-48.

Czarnitzki, D. and Kraft, K. (2007), "Spillovers of innovation activities and their profitability", Discussion Paper No. 07-073, available at: ftp://ftp.zew.de/pub/zew-docs/dp/dp07073.pdf (accessed 13.10.2018).

del Río Gonzalez, P. (2005), "Analysing the factors influencing clean technology adoption: a study of the Spanish pulp and paper industry", Business Strategy and Environment, Vol. 14, pp. 20-37.

Damanpour, F. (1996), "Organizational complexity and innovation: developing and testing multiple contingency models", Management Science, Vol. 42 No. 5, pp. 693-716.

Faber, A. and Hoppe, T. (2013), "Co-constructing a sustainable built environment in The Netherlands dynamics and opportunities in an environmental sectoral innovation system", Energy Policy, Vol. 52, pp. 628-638.

Fagerberg, J. (2005), "Innovation: a guide to the literature", in Fagerberg, J., Mowery, D. and Nelson, R.R. (Eds), The Oxford Handbook of Innovation, Oxford University Press, Oxford, pp. 1-28.

Godfray, C. et al. (2010), "People food security: the challenge of feeding 9 billion”, Science, Vol. 327, p. 812.

Gunday, G., Ulusoy, G., Kilic, K. and Alpkan, L. (2011), "Effects of innovation types on firm performance", International Journal of Production Economics, Vol. 133 No. 2, pp. 662-676.

Gunders, D. (2012), "Wasted: how America is losing up to 40 percent of its food from farm to fork to landfill", NRDC, iP:12-06-B. 
Gupta, S., Malhotra, N.K., Czinkota, M. and Foroudi, P. (2016), "Marketing innovation: a consequence of competitiveness", Journal of Business Research, Vol. 69 No. 12, pp. 5671-5681.

Gustavsson, J., Cederberg, C., Sonesson, U., van Otterdijk, R. and Meybeck, A. (2011), "Global food losses and food waste: extent, causes and prevention", FAO report, available at: www.fao.org/docrep/ 014/mb060e/mb060e00.pdf (accessed 10 August 2017).

Halpern, N. (2010), "Marketing innovation: sources, capabilities and consequences at airports in Europe's peripheral areas", Journal of Air Transport Management, Vol. 16Vol. 1. No. 2, pp. 52-58.

Hannan, M.T. and Freeman, J. (1984), "Structural inertia and organizational change", American Sociological Review, Vol. 49 No. 2, pp. 149-164.

Hofstede, G. (1980), Culture's Consequences: International Differences in Work-Related Values, Sage, Beverly Hills, CA.

Hunt, S.D. and Morgan, R.M. (1995), "The comparative advantage theory of competition", Journal of Marketing, Vol. 59 No. 2, pp. 1-15.

Hunt, S.D. and Morgan, R.M. (1996), "The resource-advantage theory of competition: dynamics, path dependencies, and evolutionary dimensions", Journal of Marketing, Vol. 60 No. 4, pp. 107-114.

Henson, S. (1996), "Demand-side constraints on the introduction of new food technologies: the case of food irradiation", in Galizzi, G. and Venturini, L. (Eds), Economics of Innovation: The Case of Food, Industry, PhysicaVerlag, Heidelberg, pp. 39-61.

Johnson, M. (2010), "Barriers to innovation adoption: a study of e-markets", Industrial Management \& Data Systems, Vol. 110 No. 2, pp. 157-174.

Klerx, L., van Mierlo, B. and Leeuwis, C. (2012), Evolution of Systems Approaches to Agri-Cultural Innovation: concepts, Analysis and Interventions, Wageningen Academic Publishers, Wageningen.

Kühne, B., Gellynck, X., Vermeire, B. and Molnár, A. (2007), "Barriers and drivers of innovation in traditional food networks", Paper presented at the 1st International European Forum on Innovation and System Dynamics in Food Networks Officially endorsed by the European Association of Agricultural Economists (EAAE), Innsbruck-lgls, available at: http://ageconsearch.umn.edu/bitstream/6617/2/sp08ku01.pdf

Lam, A. (2006), "Organizational innovation", Handbook of Innovation, Oxford University Press.

Lin, R.J., Chen, R.H. and Chiu, K.K.S. (2010), "Customer relationship management and innovation capability: an empirical study", Industrial Management \& Data Systems, Vol. 110 No. 1, pp. 111-133.

Long, T.B., Blok, V. and Coninx, I. (2016), "Barriers to the adoption and diffusion of technological innovations for climate-smart agriculture in Europe: evidence from The Netherlands, France, Switzerland and Italy", Journal of Cleaner Production, Vol. 112, pp. 9-21.

Luthra, S., Kumar, S., Kharb, R., Ansari, M.F. and Shimmi, S.L. (2014), "Adoption of smart-grid technologies: an analysis of interactions among barriers", Renewable and Sustainable Energy Reviews, Vol. 33, pp. 554-565.

Mack, F. (2018), "Factors influencing consumers' adoption of and resistance to functional food product innovation", Master thesis, University of Twente, available at: http://essay.utwente.nl/75033/1/ Mack_MA_BMS.pdf

Marra, M., Pannell, D. and Abadi Ghadim, A. (2003), "The economics of risk, uncertainty and learning in the adoption of new agricultural technologies: where are we on the learning curve?".

Martinez, M.G. and Briz, J. (2000), "International Food and Agribusiness Management Review", Journal of Business Research, Vol. 3 No. 2, p. 22.

Medrano-Sáez, N. and Olarte-Pascual, M.C. (2012), Marketing Innovation as an Opportunity in a Situation of Uncertainty: The Spanish Case. Soft Computing in Management and Business Economics, Springer, pp. 327-341.

Mol, M.J. and Birkinshaw, J. (2009), "The sources of management innovation: when firms introduce new management practices", Journal of Business Research, Vol. 62 No. 12, pp. 1269-1280.

Montalvo, C. (2008), "General wisdom concerning the factors affecting the adoption of cleaner technologies: a survey 1990e2007", Journal of Clean Production, Vol. 16, pp. 7-13.

Moreira, J., Silva, M.J., Simoes, J. and Sousa, G. (2012), "Marketing innovation: study of determinants of innovation in the design and packaging of goods and services - application to Portuguese firms", Contemporary Management Research, Vol. 8 No. 2, pp. 117-130. 
Naidoo, V. (2010), "Firm survival through a crisis: the influence of market orientation, marketing innovation and business strategy", Industrial Marketing Management, Vol. 39 No. 8, pp. 1311-1320.

OECD (2005), Oslo Manual: Guidelines for Collecting and Interpreting Innovation Data, 3rd ed., Organisation for Economic Co-operation and Development (OECD), Paris.

Polder, M., van Leeuwen, G., Mohnen, P. and Raymond, W. (2010), "Product, process and organizational innovation: drivers", Complementarity and Productivity Effects, DRUID Working Paper, pp. 10-24.

Ren, L., Xie, G. and Krabbendam, K. (2010), "Sustainable competitive advantage and marketing innovation within firms, a pragmatic approach for Chinese firms", Management Research Review, Vol. 33 No. 1, pp. 79-89.

Rogers, E.M. (2003), Diffusion of Innovation, 5th ed., Free Press, New York, NY.

Salhofer, S., Obersteiner, G., Schneider, F. and Lebersorger, S. (2008), "Potentials for the prevention of municipal solid waste", Waste Management, Vol. 28 No. 2, pp. 245-259.

Schubert, T. (2010), "Marketing and organisational innovations in entrepreneurial innovation processes and their relation to market structure and firm characteristics", Review of Industrial Organization, Vol. 36 No. 2, pp. 189-212.

Shergill, G.S. and Nargundkar, R. (2005), "Market orientation, marketing innovation as performance drivers: extending the paradigm", Journal of Global Marketing, Vol. 19 No. 1, pp. 27-47.

Schmidt, R. and Rammer, C. (2007), "Non-technological and technological innovation: strange bedfellows?", DRUID Discussion Paper No. 07-052, The Open Access Publication Server of the ZBW Leibniz Information Centre for Economics, available at: http://econstor.eu/bitstream/10419/24623/1/ dp07052.pdf (accessed 6 September 2017).

Silva, M.J.M., Simões, J., Moreira, J. and Sousa, G. (2012), "Investment and expenditure on innovation activities and innovative capability: empirical evidence from Portuguese services firms and KIBS", International Business Research, Vol. 5 No. 2, pp. 114-122.

Slater, S.F. and Narver, J.C. (1994), "Market orientation, customer value, and superior performance", Business Horizons, Vol. 37 No. 2, pp. 22-28.

Sporleder, L.T., Hooker, N.H., Shanahan, C.J. and Bröring, S. (2008), "Innovation in food products: first-mover strategy and entropy metrics", Presented at International Food and Agribusiness Management Symposium, Monterey, CA, 14-17 June, available at: http://edepot.wur.nl/36262 (accessed 13 September 2018).

Sood, A. and Tellis, G.J. (2009), "Do innovations really pay off? Total stockmarket returns to innovation", Marketing Science, Vol. 28 No. 3, pp. 442-456. volno

Stenmarck, Å Hansen, O.J., Silvennoinen, K., Werge, M. and Katajajuuri, J.M. (2011), Initiatives on Prevention of Food Waste in the Retail and Wholesale Trades, IVL - Swedish Environmental Research Institute, Stockholm.

Stuart, T. (2009), Waste - Uncovering the Global Food Scandal, Penguin books, London. p. 451.

The Guardian (2016), "Asda puts UK's first supermarket wonky veg box on sale”, Friday, 5 February, available at: www.theguardian.com/environment/2016/feb/05/asda-puts-uks-first-supermarket-wonky-veg-box-on-sale

Tödtling, F., Lehner, P. and Kaufmann, A. (2009), "Do different types of innovation rely on specific kinds of knowledge interactions?", Technovation, Vol. 29 No. 1, pp. 59-71.

Triguero, A., Córcoles, D. and María, C.C. (2013), "Differences in innovation between food and manufacturing firms: an analysis of persistence", Agribusiness, Vol. 29 No. 3, pp. 273-292.

Uzkurt, C., Rachna, K., Kimzan, S.H. and Gözde, E. (2013), "Role of innovation in the relationship between organizational culture and firm performance: a study of the banking sector in Turkey", European Journal of Innovation Management, Vol. 16 No. 1, pp. 92-117.

Waarts, Y., Eppink, M., Oosterkamp, E., Hiller, S., van der Sluis, A. and Timmermans, T. (2011), "Reducing food waste. Obstacles experienced in legislation and regulations. LEI - report 2011-59", available at: http://edepot.wur.nl/188798 (accessed 13 September, 2018).

Weber, K.M. and Rohracher, H. (2012), "Legitimizing research, technology and innovation policies for transformative change: combining insights from innovation systems and multi-level perspective in a comprehensive 'failures' framework”, Research Policy, Vol. 41 No. 6, pp. 1037-1047.

Winter, S.G. (2006), "The logic of appropriability: from Schumpeter to arrow to Teece", Research Policy, Vol. 35 No. 8 , pp. 1100-1106. 
Walker, R.M. (2004), "Innovation and organisational performance: evidence and a research agenda", Advanced Institute of Management Research Paper (002).

Walker, R.M. (2008), "An empirical evaluation of innovation types and organizational and environmental characteristics: towards a configuration framework", Journal of Public Administration Research and Theory, Vol. 18 No. 4, pp. 591-615.

Wu, L.Y. (2010), "Which companies should implement management innovation? A commentary essay", Journal of Business Research, Vol. 63 No. 3, pp. 321-323.

WRAP (2011), Hovis; Link Consumer Strategies; Campden BRI. Reducing Household Bakery Waste, WRAP, Banbury.

WRAP (2012), Reducing Supply Chain and Consumer Potato Waste, WRAP, Banbury.

Zhou, W. (2013), "Food waste and recycling in China: a growing trend?", Worldwatch Trends, available at: www.worldwatch.org/food-waste-and-recycling-china-growing-trend-1 (accessed 10 August 2017).

\section{Further reading}

Daft, R.L. (1978), "A Dual-Core model of organizational innovation", Academy of Management Review, Vol. 21, pp. 193-210.

Damanpour, F. and Evan, W.M. (1984), "Organizational innovation and performance: the problem of organizational lag", Administrative Science Quarterly, Vol. 29 No. 3, pp. 392-402.

EU FP7 Fusions Project (2012/2016), available at: http://eu-fusions.org/index.php/publications (accessed 6 September 2017).

EU H2O२О REFRESH Project (2015/2019), available at: http://eu-refresh.org/results (accessed 6 September 2017).

Kalyanam, K., Lal, R. and Wolfram, G. (2006), "Future store technologies and their impact on grocery retailing", in Kraft, M. and Mantrala, M. (Eds), Retailing in the 21st Century: Current and Future Trends, Springer, New York, NY, Berlin, Heidelberg, pp. 95-112.

Shankar, V. and Balasubramanian, S. (2009), "Mobile marketing synthesis and prognosis", Journal of Interactive Marketing, Vol. 23 No. 2, pp. 118-129.

Shankar, V., Inman, J., Murali, M., Kelley, E. and Rizley, R. (2011), "Innovations in shopper marketing: current insights and future research issues”, Journal of Retailing, Vol. 87 No. S1, pp. S29-S42.

Author affiliations

Lusine Aramyan is based at Wageningen Economic Research, Wageningen University and Research, Wageningen, The Netherlands.

Matthew Grainger is based at the Norwegian Institute for Nature Research, Trondheim, Norway.

Katja Logatcheva is based at Wageningen University and Research, Wageningen, The Netherlands.

Simone Piras is based at The James Hutton Institute, Aberdeen, UK.

Marco Setti is based at the University of Bologna, Bologna, Italy.

Gavin Stewart is based at Newcastle University, Newcastle upon Tyne, UK.

Matteo Vittuari is based at the University of Bologna, Bologna, Italy.

\section{Corresponding author}

Lusine Aramyan can be contacted at: lusine.aramyan@wur.nl

For instructions on how to order reprints of this article, please visit our website: www.emeraldgrouppublishing.com/licensing/reprints.htm

Or contact us for further details: permissions@emeraldinsight.com 